\title{
Accumulation of Heavy Metals and Poly Aromatic Hydrocarbons in Marine Fishes around offshore Oil and Gas fields in west coast of India
}

\author{
Sonali Kumbhare*, Dilip S. Ramteke and Pravin Charde \\ Sevadal Mahila Mahavidhyalaya, Nagpur, India \\ *Corresponding author
}

\section{A B S T R A C T}

Accelerated exploitation of oil and gas resources planned and implemented by ONGC and BGEIPL in west coast offshore region would result into stress particularly on marine environment. The long term physical, chemical and biological changes due to routine discharges from offshore installations can best be assessed through a study on accumulation of hydrocarbons and heavy metals in fishes, plankton and sediments which together form biotic and abiotic components of marine environment. The accumulation of hydrocarbon and heavy metals are considered as major threat to biota when concentration levels exceed the levels of toxicity either in abiotic or biotic environment. The existing scenario is based on the data generated in the offshore area of west cost of India. Studies were carried out to find out the levels of hydrocarbons and heavy metals and their accumulation in marine fish tissues of liver, muscle, grills and reproductive organs in and around offshore oil and natural Gas field in west cost of India. Data was collected for post monsoon and pre-monsoon seasons. It was observed that levels of hydrocarbons in gills were found to be high $(2128 \mu \mathrm{g} / \mathrm{g})$ during pre-monsoon and might be the primary uptake site of hydrocarbons through water and the micellar layer in grills might be playing an important role in absorption/adsorption of hydrophobic hydrocarbons. However, hydrocarbons levels in the water column, during the study were observed in the range of ND -2.5 $\mu \mathrm{g} / \mathrm{l}$, presence of high levels of hydrocarbons in fish tissues, could be explained only through the process of both bioaccumulation and biomagnification. Accumulation of hydrocarbons in marine fishes was studied with respect to its food value. Liver was considered as an indicator organ to assess the degree of detoxification and deposition. High food value fishes were observed to be prone to accumulation in following descending order: Scoliodon laticaudus $>$ Epinephelus diacanthus $>$ Psettodes erumei $>$ Scoliodon sorrowkowah whereas luxury food value fish species showed affinity in following order: Scomberomorous guttatus $>$ Eleutronema tetradactylum $>$ Eleuthronema heptadactylus and Pampus argentenus. Concentration levels of heavy metals in fish tissues revealed maximum bioaccumulation in liver, the site of detoxification. Levels of cadmium were found to be lower than the normally reported values $(0.1$ to $2.1 \mu \mathrm{g} / \mathrm{g})$ except in a few cases. In present study, levels of copper were observed to be higher than reported value $(2.2 \mu \mathrm{g} / \mathrm{g})$ and exceeded the human taste threshold value of $<0.5$ to $0.75 \mu \mathrm{g} / \mathrm{g}$, in both pre-monsoon and post-monsoon seasons with levels in premonsoon recorded higher values as compared to post-monsoon. There was no seasonal variation in levels of lead, zinc and chromium. Zinc levels in fish have been observed to seldom exceed $50 \mu \mathrm{g} / \mathrm{g}$. however, in many cases, zinc exceeded this value (as high as $161.2 \mu \mathrm{g} / \mathrm{g}$ in Megalaspis cordyla) in testis/ ovaries and also in other tissues. Accumulation of heavy metals in fishes was studied based on their food value. In this case also, liver was considered as indicator organ to assess the degree of detoxification and deposition. High food value fishes were observed to be prone to accumulation in following descending order: Scoliodon sorrowkowah > Scoliodon laticaudus > Eleuthronema diacanthus $>$ Psettodes erumei, whereas for luxury food value, the sequence in descending order was Pampus argenteus > Scomberomorous guttatus> Eleuthronema heptadactylus and Eleuthronema tetradactylum. Levels of heavy metals recorded in fish tissues during the present study corroborates with those reported for fishes from Northern India Ocean. 


\section{Introduction}

Offshore petroleum activity for the recovery oil and gas is one of the major human activities in the oceans of the continental margin. Assessing the environmental ramifications of this activity has been a highly-funded research topic in continental self-oceanography over the past decade (Boothe et al., 1989). These studies are of paramount importance to infer health hazards to man, caused through contaminated fishery products and the damage inflicted on marine or estuarine organisms and the ecosystems (Das et al., 2001).

Offshore activities generated a number of wastes, including discharges from deck drainage, domestic waste, drilling fluids and cuttings and production water (NEB et al., 2002). Drilling fluids and cuttings are the major wastes created during oil and gas exploration and developmental activities (Offshore Oil and Gas Environmental Effects). The significant of environmental impacts from operational waste discharges has resulted in the establishment of costly mitigation measures and Environmental Effects Monitoring (EEM) programs at offshore oil and gas production sites the world over. The so-called 'taining' of fish by oil spills has been recognized for many years. It has been widely assumed that fish 'tainted' by oil will be again fit for human consumption after 2 weeks to several months (Simpson, 1968). Hence accumulation of hydrocarbons and toxic metals in different organs of marine organisms and their subsequent transfer to man through the food chain is of great concern. Information on the accumulation of hydrocarbons and heavy metals within individual species and their tissues is essential in planning a monitoring study for long term data collection of hydrocarbons and heavy metals levels in species of fish. During earlier stages of marine pollution research, it became clear that an accumulation of toxic elements and organic compounds results too, which according to current knowledge, have no positive metabolic function; on the contrary, they can manifest harmful effects. Now following important first stage results, research is beginning to explain the different and mechanisms of uptake which are evidently different from substance to substance, to localize the point of storage, and to understand the mechanisms of elimination. Here too, it will not be possible to make sure judgments for a number of years. To date, interest has centered only on those substances which seem to be of direct importance to those fish that man uses as a source of nutrition.

Accumulation of petroleum hydrocarbons by marine biota is dependent on the biological availability of hydrocarbons in soluble and droplet forms, the duration of exposures and the metabolic transformations. Chemical factors such as solubility, absorptiondesorption kinetics, octanol/ water partition coefficient and biological factors such as solubility, adsorption-desorption kinetics, octanol/water partition coefficients and biological factors such as deposition in body lipid, feeding habits and metabolism affect the bioaccumulation of hydrocarbons in marine organisms.

Biological uptake of hydrocarbons from contaminated sediments is governed by desorption of hydrocarbons from sediment particles into interstitial waters. Uptake of compounds may occur through adsorption on to body surfaces, water exchange at respiratory and feeding surfaces and ingestion of food and detrital particles. Removal may occur through active mechanisms such as hydrocarbon metabolism and the excretion of metabolized byproducts, passive mechanism such as diffusive exchange and the production of particulate products (eggs, molts and faeces). 
Metals exist in marine environment in an assimiable form that usually undergoes bioaccumulation through food chain. Hence, elements persisting even at lower concentrations in water, may be accumulated several thousand folds in certain organisms. The extent of occurrence or accumulation of trace metals by organisms in different tissues is dependent on their route of entry i.e. either from surrounding medium or in the form of food and chemical form (complex or organo metallic complex) of a constituent available in the media. Metals are eliminated from the body of marine fishes, mainly in three ways, by faecal pellet formation, soluble excreation and or production. Therefore, the total content of metals in any particular fish depends on its uptake and excretion rates.

India with a coastline of $6100 \mathrm{~km}$, continental shelf of 0.451 million sq. km. and Exclusive Economic Zone (EEZ) of 2.02 million sq. $\mathrm{km}$ has rich marine fishery potential. It is also established that coastal waters, particularly off west coast are highly productive and act as spawning and nursery grounds for several commercially important fish species. The fish potential of this area is estimated to be $25 \%$ of the total fish production in the state of Maharashtra.

The west coast offshore region has been divided into four major oil/gas fields viz. Bombay high, Bassein, Heera-Ratna and Tapti (Fig. 1). The oil/gas fields are located between latitude $18^{\circ} 12^{\prime \prime} \mathrm{N}$ to $20^{\circ} 50^{\prime \prime} \mathrm{N}$ and between longitude $71^{\circ} 25^{\prime \prime} \mathrm{E}$ to $72^{\circ} 24^{\prime \prime} \mathrm{E}$. Substantial infrastructure has been established by ONGC on this relatively benign environment. As of now, offshore operations extend up to $180 \mathrm{~km}$ from Indian west coast in Arabian Sea. Operational activities (spills of crude oil from blow outs, surface spills of crude from platforms, or slow chronic releases associated with produced water or oil bearing cuttings created during the drilling process) inevitably, interact with the environment through short and long-term physical, chemical and biological changes. There changes, unless adequate preventive and control measures are planned and implemented, would cause significant damage to marine life.

\section{Materials and Methods}

In order to assess the hydrocarbon and heavy metals distribution in marine fishes, a research vessel, MFV-Saraswati, fitted with appropriate equipment's for collection of fish samples and facilities for their storages, was engaged from Central Institute for Fisheries Education (CIFE), Bombay.

Fish species were collected within the study area at 11 locations in post-monsoon season (Fig.2) and at 10 locations in pre-monsoon season (Fig. 3) by operation a bottom trawl net. Fishes were identified on board and the tissues viz. muscles, gonad, liver and gills, were dissected out. Each of the tissues were weighed and preserved, deep frozen, for subsequent analysis in laboratory.

While analyzing hydrocarbons, ten grams of each dissected tissue was homogenized and saponified with $4 \mathrm{~N} \mathrm{NaOH}$ at $90^{\circ} \mathrm{C}$ for $2 \mathrm{hrs}$. After cooling the sample, $20 \mathrm{ml}$. of carbon tetrachloride $\left(\mathrm{CCl}_{4}\right)$ was added for extraction. The suspension was centrifuged at $2000 \mathrm{rpm}$ for $10 \mathrm{~min}$ and the solvent layer was carefully withdrawn with a $30 \mathrm{ml}$. syringe fitted with long needle. The extract was transferred to $100 \mathrm{ml}$ volumetric flask through sodium sulphate. The aqueous suspension remaining in the centrifuge tube was re-extracted twice, with $20 \mathrm{ml}$ portion of carbon tetrachloride in a similar manner. Final volume of $\mathrm{CCl}_{4}$ was made to $100 \mathrm{ml}$.

Prior to analysis, extract was passed through silica gel for removal of soluble grease material. Total hydrocarbons were estimated using fluorescence spectrophotometer. 
While analyzing for heavy metals, each of the fish tissues (5 g) was digested in equal proportion $(5 \mathrm{ml}$ each) of concentrated sulphuric acid $\left(\mathrm{H}_{2} \mathrm{SO}_{4}\right)$ and nitric acid $\left(\mathrm{HNO}_{3}\right)$ in Teflon screw cap beakers on a hot plate. Samples were concentrated during digestion and redissolved in $10 \% \mathrm{HNO}_{3}$. Heavy metals were estimated in these samples, using Inductively Coupled Plasma (ICP).

\section{Results and Discussions}

\section{Accumulation of hydrocarbons}

Fishes, because of their relatively large size and ease of identification, have long been used as indicators of environmental change. The mobility and sensory perceptions of many species allow them to avoid environmental perturbations, and thus they can show a rapid response to any alternation in environmental stress. Fish stocks are often defined as resilient if they are able to sustain environmental change without noticeable to primary factors such as temperature, salinity, upwelling, pollutants etc.

Accumulation of polycyclic hydrocarbons (PAH) in fish has been widely reported and it has been shown that naphthalenes in particular are absorbed. A recent investigation on the accumulation and distribution of hydrocarbons in fish from Mediterranean reports, accumulation of hydrocarbons in fish liver and muscle suggesting that liver and muscle may act as indicator organs of acute and chronic exposure to hydrocarbon pollutants respectively.

Data on accumulation of hydrocarbons in tissues of liver, muscle and reproductive organs in fishes collected from west coast offshore region during present survey reveals that the levels of hydrocarbon were marginal limits in most of the cases. A few species however, were observed to contain hydrocarbon as high as 1535, 1161 and 779 $\mu \mathrm{g} / \mathrm{g}$ in liver, reproductive organs and muscle respectively. Through, hydrocarbon levels in the water column during the present study were observed in the range of ND-2.5 $\mu \mathrm{g} / \mathrm{l}$, presence of high levels of hydrocarbons in fish tissues could be explained only through the process of both bioaccumulation and biomagnifications. Levels of hydrocarbons in gills of fishes collected during survey have been observed to be very high $(2128 \mu \mathrm{g} / \mathrm{g})$ and implies absorption directly from water.

Accumulation of hydrocarbons and their toxicity was studied in fish with respect to its food value. Liver was considered as indicator organs to assess the degree of detoxification and deposition. High food value fishes were observed to be prone to accumulation of hydrocarbon was observed to be maximum in gills followed by liver and muscle. Total hydrocarbon levels in cod liver (50-2300 $\mu \mathrm{g} / \mathrm{g}$ ) reported in North Sea off coast of Norway has been observed to be either comparable or more than the observed values in the present study (ND-1535 $\mu \mathrm{g} / \mathrm{g}$ ). Hydrocarbon levels observed in planktons and fish tissues in the present study are in harmony with those reported by earlier workers (Table 1).

Toxicity of petroleum hydrocarbons to fish has been reported for Mugil cephalos in terms of crude oil as $4-5 \mu \mathrm{g} / \mathrm{g}$ for 56 days and is known to cause fin erosion. The fish species Clopea harengus at $0.9 \mathrm{ppb}$ for $24 \mathrm{~h}$ in terms of benzene causes hyperplasis has been reported in Menidia menidia for crude oil concentration of $140 \mathrm{ppb}$ for $168 \mathrm{~h}$. Levels of hydrocarbon observed in water column are much below the reported levels at which toxic effects are pronounced. In the present study, range and averages of hydrocarbon levels in liver, reproductive organs, muscle and gills of fishes collected at various locations in postmonsoon and pre-monsoon seasons are summarized in tables 2 and 3 respectively. 
Table.1 Levels of hydrocarbon in marine organisms

\begin{tabular}{|c|c|c|c|c|}
\hline $\begin{array}{l}\text { Sr. } \\
\text { no. }\end{array}$ & Organism & $\begin{array}{l}\text { Type } \\
\text { Hydrocarbon }\end{array}$ & Concentration & Source \\
\hline 1. & Atlantic Cod & Total hydrocarbon & $\begin{array}{l}345 \mathrm{mgkg}^{-1} \text { dry } \\
\text { weight }\end{array}$ & (7) \\
\hline 2. & Greenland halibut & Total hydrocarbon & $\begin{array}{l}230 \mathrm{mgkg}^{-1} \text { dry } \\
\text { weight }\end{array}$ & (7) \\
\hline 3. & Ocean Perch & Total hydrocarbon & $\begin{array}{l}110 \mathrm{mgkg}^{-1} \text { dry } \\
\text { weight }\end{array}$ & (7) \\
\hline 4. & Mixed Plankton & $\begin{array}{l}\text { Benzo(a)Pyrene } \\
(\mathrm{BaP})\end{array}$ & $\begin{array}{l}\text { Upto } 400 \mathrm{mgkg}^{-1} \text { dry } \\
\text { weight }\end{array}$ & (8) \\
\hline 5. & Calamus finmarchicus & Pristane & $\begin{array}{l}0.46-0.68 \% \text { dry } \\
\text { weight }\end{array}$ & (8) \\
\hline 6. & Sagitta elegans & Pristane & $0.02 \%$ dry weight & (8) \\
\hline 7. & $\begin{array}{l}\text { Fishes of Arbian Sea } \\
\text { indicator organ-liver }\end{array}$ & Total hydrocarbon & $\begin{array}{l}\text { ND-1535 } \mu g^{-1} \text { wet } \\
\text { weight }\end{array}$ & $\begin{array}{l}\text { Present } \\
\text { survey }\end{array}$ \\
\hline 8. & $\begin{array}{l}\text { Seston (mixed plankton) of } \\
\text { Arabian Sea }\end{array}$ & Total hydrocarbon & $\begin{array}{l}0-144 \mathrm{mgkg}^{-1} \text { wet } \\
\text { weight }\end{array}$ & $\begin{array}{l}\text { Present } \\
\text { survey }\end{array}$ \\
\hline
\end{tabular}

Table.2 Range and averages of hydrocarbons and heavy metals concentration $(\mu \mathrm{g} / \mathrm{g})$ in fish tissues: liver

\begin{tabular}{|c|c|c|c|c|}
\hline Sr. no. & Parameter & & Post-monsoon & Pre-monsoon \\
\hline 1. & Cadmium & $\mathrm{X}$ & 3.0 & 1.6 \\
& & Range & $0-26.9$ & $0-31.6$ \\
\hline 2. & Copper & $\mathrm{X}$ & 8.5 & 4.8 \\
& & Range & $0-50.0$ & $0-42.0$ \\
\hline 3. & Chromium & $\mathrm{X}$ & 7.5 & 4.8 \\
& & Range & $0-127.7$ & $0-112.5$ \\
\hline 4. & Lead & $\mathrm{X}$ & 40.3 & 5.5 \\
& & Range & $0-577.9$ & $0-131.3$ \\
\hline 5. & Zinc & Xange & $0-128.6$ & 24.9 \\
& & $\mathrm{X}$ & 134.8 & $0-92.7$ \\
\hline 6. & Hydrocarbon & Range & $0-1535$ & $0-1310$ \\
\hline
\end{tabular}


Table.3 range and averages of hydrocarbons and heavy metals concentration $(\mu \mathrm{g} / \mathrm{g})$ in fish tissues: testis / ovaries

\begin{tabular}{|c|c|c|c|c|}
\hline Sr. no. & Parameter & & Post-monsoon & Pre-monsoon \\
\hline 1. & Cadmium & X & 2.4 & 0.75 \\
& & Range & $0-19.4$ & $0-19.4$ \\
\hline 2. & Copper & X & 7.5 & 7.7 \\
& & Range & $0-50.0$ & $0-509$ \\
\hline 3. & Chromium & X & 14.9 & 1.30 \\
& & Range & $0-220.8$ & $0-31.6$ \\
\hline 4. & Lead & Xange & $0-903.6$ & 4.11 \\
& & X & 41.3 & $0-92.0$ \\
\hline 5. & Zinc & Range & $0-161.2$ & $0-98.0$ \\
\hline 6. & Hydrocarbon & X & 48.7 & 93.1 \\
& & Range & $0-606$ & $0-1161$ \\
\hline
\end{tabular}

Table.4 Range and averages of hydrocarbons and heavy metals concentration $(\mu \mathrm{g} / \mathrm{g})$ in fish tissues: muscles

\begin{tabular}{|c|c|c|c|c|}
\hline Sr. no. & Parameter & & Post-monsoon & Pre-monsoon \\
\hline 1. & Cadmium & X & 0.02 & 0.68 \\
& & Range & $0-0.5$ & $0-7.1$ \\
\hline 2. & Copper & X & 0.76 & 2.23 \\
& & Range & $0-2.8$ & $0-137.0$ \\
\hline 3. & Chromium & X & 0.40 & 0.41 \\
& & Range & $0-1.5$ & $0-5.6$ \\
\hline 4. & Lead & X & 0.49 & 2.85 \\
& & Range & $0-2.4$ & $0-82.2$ \\
\hline 5. & Zinc & X & 8.04 & 22.11 \\
& & Range & $0-30.2$ & $0-91.0$ \\
\hline 6. & Hydrocarbon & X & 88.20 & 239.9 \\
& & Range & $0-454$ & $0-779$ \\
\hline
\end{tabular}


Table.5 range and averages of hydrocarbons and heavy metals concentration $(\mu \mathrm{g} / \mathrm{g})$ in fish tissues: gills

\begin{tabular}{|c|c|c|c|c|}
\hline Sr. no. & Parameter & & Post-monsoon* & Pre-monsoon \\
\hline 1. & Cadmium & $\begin{array}{c}\mathrm{X} \\
\text { Range }\end{array}$ & - & $\begin{array}{c}1.02 \\
0-29.3\end{array}$ \\
\hline 2. & Copper & $\begin{array}{c}\mathrm{X} \\
\text { Range }\end{array}$ & - & $\begin{array}{c}1.14 \\
0-6.5\end{array}$ \\
\hline 3. & Chromium & $\begin{array}{c}\mathrm{X} \\
\text { Range }\end{array}$ & - & $\begin{array}{c}0.84 \\
0-9.5\end{array}$ \\
\hline 4. & Lead & $\begin{array}{c}\mathrm{X} \\
\text { Range }\end{array}$ & - & $\begin{array}{c}1.91 \\
0-12.0\end{array}$ \\
\hline 5. & Zinc & $\begin{array}{c}\mathrm{X} \\
\text { Range }\end{array}$ & - & $\begin{array}{c}34.49 \\
0-12.0\end{array}$ \\
\hline 6. & Hydrocarbon & $\begin{array}{c}\mathrm{X} \\
\text { Range }\end{array}$ & - & $\begin{array}{l}297.06 \\
0-2128\end{array}$ \\
\hline
\end{tabular}

* Data not collected

$\mathrm{X}$ : Mean values

Values of $X$ and range are expressed as $\mu \mathrm{g} / \mathrm{g}$

Figure.1 Sampling location

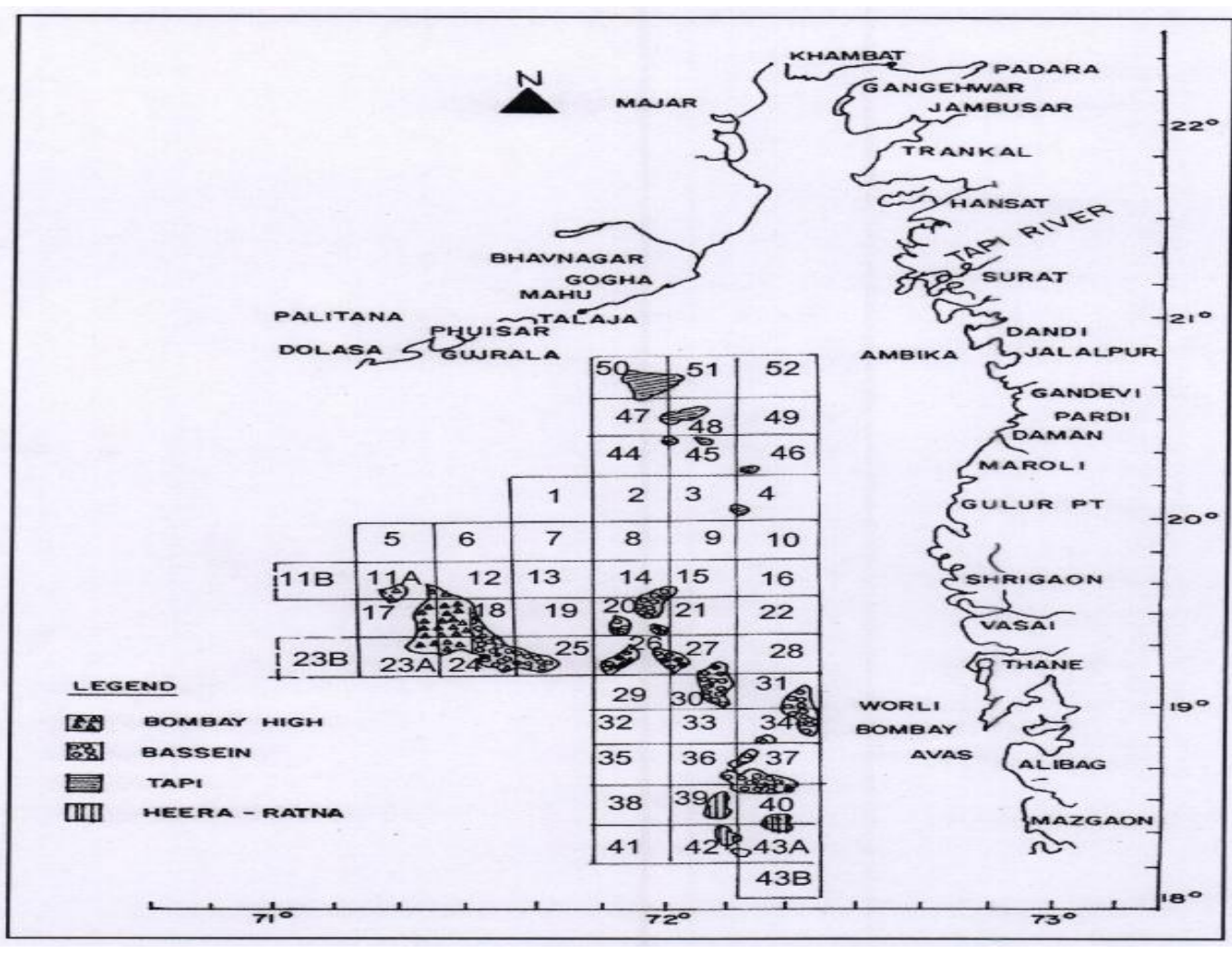


Figure.2 Fish sampling location in West Coast offshore (post-monsoon)

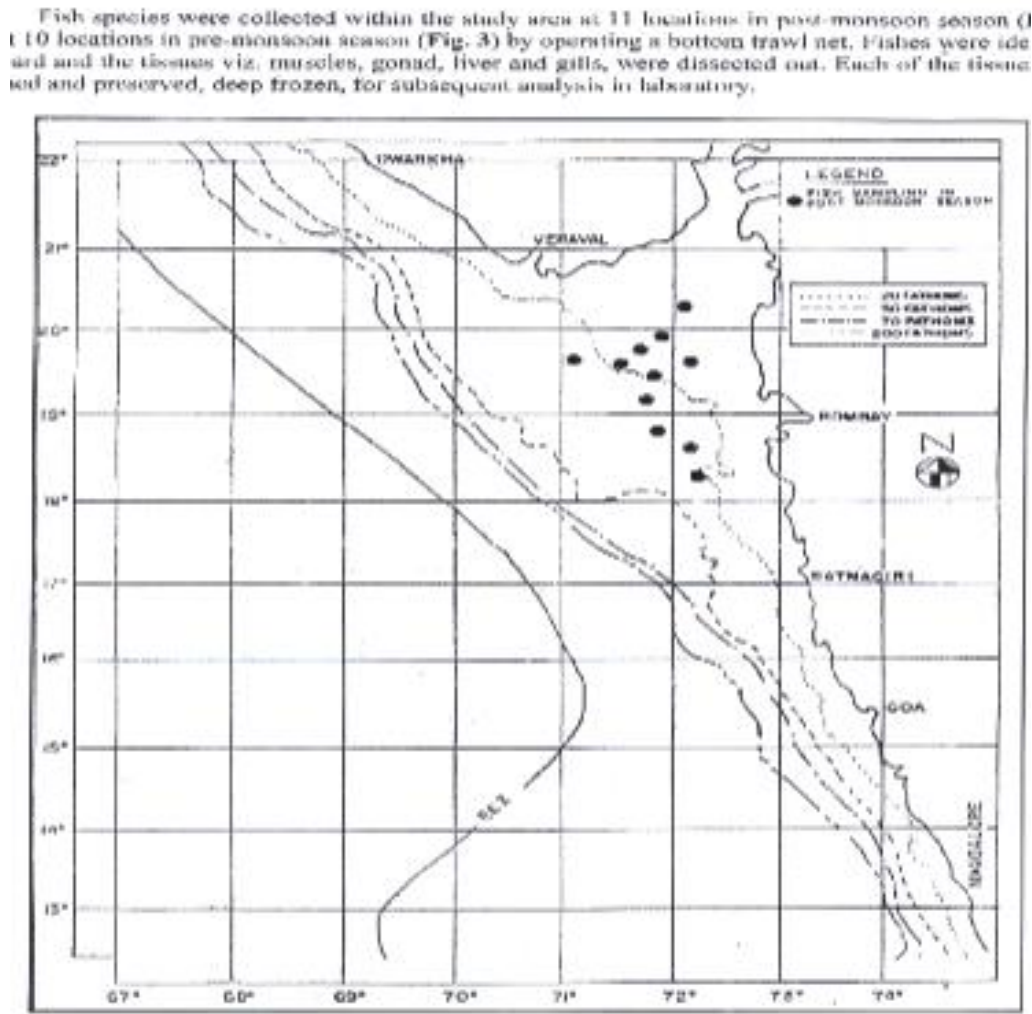

Figure.3 Fish sampling location in West Coast offshore (Pre-monsoon)

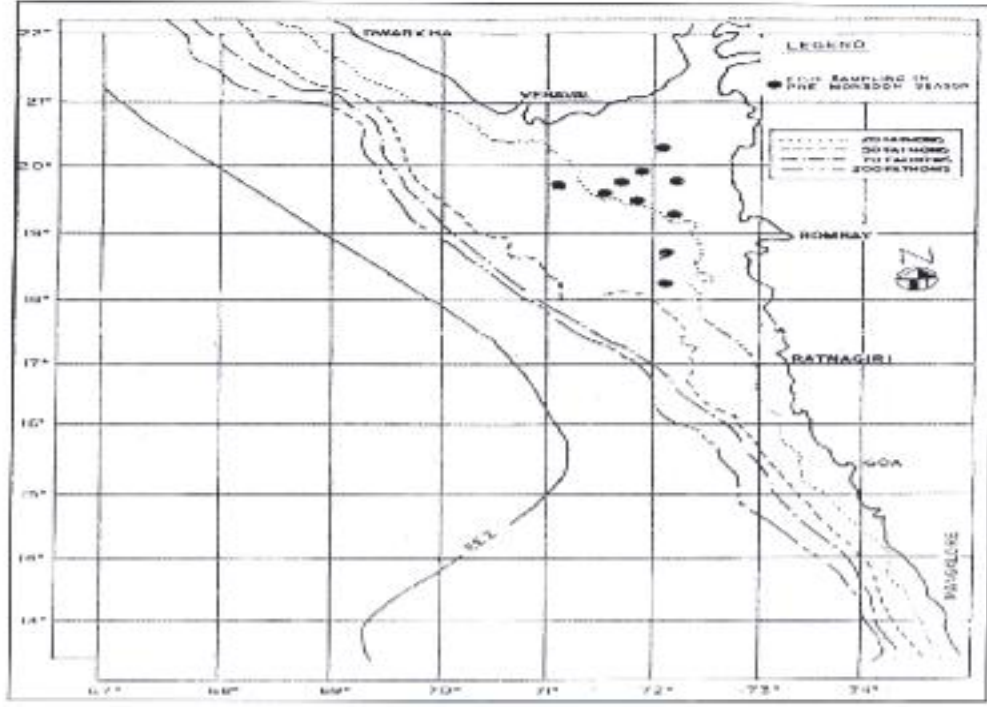

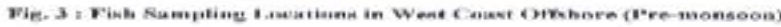

The hydrocarbon levels reported in fish tissues ranged between ND-1535, ND - 1161, ND 779 and ND - $2128 \mu \mathrm{g} / \mathrm{g}$ for liver, gonads, muscle and gills respectively and were below the detectable limits in most of the cases. Levels of hydrocarbon in gills were observed to be very high $(2128 \mu \mathrm{g} / \mathrm{g})$ during pre-monsoon which indicates that gills might be the primary site of uptake of hydrocarbons through water and the micellar layer in gills may be playing and important role in absorption of hydrophobic hydrocarbon. 
Accumulation of hydrocarbons in marine fishes was studied with respect to its food volue. Liver was considered as indicator organ to assess the degree of detoxification and deposition. High food value fishes were observed to be prone to accumulation in following descending order: Scoliondon laticaudus $>$ Epinephelus diacanthus > Psettodes erumei > Scoliodon sorrowkowah where luxury food value fish species showed affinity in following order: Scomberomorous guttatus > Eleuthronema tetradactylum > Eleuthronema heptadactylus and Pampus argenteus. Specific correction between accumulation of hydrocarbons in the organisms and background levels of hydrocarbons in water and sediment could not be observed. This could be attributed to the fact that uptake of hydrocarbons by fishes is depended on the bioavailability and composition of the hydrocarbon mixtures (hydrophobicity and hydrophilicity), the duration of exposure and nutritional status of the fish, its lipid content, filtration rate and habitat. Further, overall accumulation is related to rate of uptake and rate of depuration, which is governed by solubility, molecular weight and octanol/ water partition co-efficient of hydrocarbon. Levels of hydrocarbons in fish have been reported as $0.1-10 \mu \mathrm{g} / \mathrm{g}$ in areas not exposed to high levels of hydrocarbon and 10 to 100 times of these levels could be observed in highly hydrocarbon polluted areas. The observed levels of hydrocarbons in present study are however, lower than the one reported in non-polluted areas with a few exceptions (Mehta et al., 1994).

\section{Bioaccumulation of heavy metals}

Effect of heavy metal pollution on aquatic environment is highly variable. Several elements are essential for life processes at trace levels, while at high concentrations they become toxic. Most of the heavy metals may be of immediate concern and lead to undesirable long term impacts on marine environment. The physico-chemical form in which a metal exists in the environment depends upon its physical, chemical and biological interactions with various constituents of the environmental component. Most of the elements are found in combined state, either as sulfide or a complex mineral containing oxygen, silicon and sulfide. Bacterial action also transforms metals into various physico-chemical forms.

Metals exist in marine environment in an assimiable form that usually undergoes bioaccumulation through food chain. Hence, elements persisting even at lower concentrations in water, may be accumulated several thousand folds in certain organisms. The extent of occurrence or accumulation of trace metals by organisms in different tissues is dependent on their route of entry i.e. either from surrounding medium or in the form of food and chemical form of a constituent available in the media. Based on laboratory studies with the crab Seylla serrata, the principal route of entry of $\mathrm{Cu}, \mathrm{Hg}$ and $\mathrm{Cd}$ seems to be food, whereas other metals viz. $\mathrm{Zn}, \mathrm{Mn}, \mathrm{Co}, \mathrm{Ni}$ and $\mathrm{Fe}$, entrain through water. The metals are eliminated from the body of marine fishes, mainly in three ways; by faecal pellet formation, soluble excretion and/or production. Therefore, the total content of metals in any particular fish depends on its uptake and excretion rates.

In the present study accumulation of heavy metals levels in liver, reproductive organs, muscle and gills of fishes are found out during post-monsoon and pre-monsoon seasons and summarized in tables 4 and 5, respectively.

Distribution of heavy metals in fish tissues revealed maximum bioaccumulation in liver, the site of detoxification. Levels of cadmium were found to be lower than the normally reported values (01 to $2.1 \mu \mathrm{g} / \mathrm{g}$ ) except in a few cases. Copper levels were observed to be more in gills. In the present study, levels of copper were observed to be higher than reported value $(2.2 \mu \mathrm{g} / \mathrm{g})$ and exceeded the human taste threshold value of $<0.5$ to $0.75 \mu \mathrm{g} / \mathrm{g}$, in both pre-monsoon and post monsoon seasons with levels in pre-monsoon recorded higher values as compared to post-monsoon. There was no seasonal variation in levels of lead, zinc and chromium. Zinc levels in fish have been 
observed to seldom exceed $50 \mu \mathrm{g} / \mathrm{g}$. However, in many cases, zinc exceeded this value (as high as $161.2 \mu \mathrm{g} / \mathrm{g}$ in Megalaspis cordyla) in testis / ovaries and also in other tissues. Accumulation of heavy metals in fishes was studied based on their food value. In this case also, liver was considered as an indicator organ to assess the degree of detoxification and deposition. High food value fishes were observed to be prone to accumulation in following descending order: Scoliodon sorrowkowah> Scoliodon laticaudus> Eleuthronema diacanthus > Prettodes erumei, whereas for luxury food value, the sequence in descending order was Pampus argenteus > Scomberomorous guttatus > Eleuthronema heptadactylus and Eleuthronema tetradactylum.

This study concludes that the quantities of hydrocarbons detected in liver, reproductive organs, muscles and gills of fishes were lower than the levels stipulated for fishes collected from contaminated area, except for a few cases. The hydrocarbon levels in the water column, during the present study observed in the range of ND-2.5 $\mu \mathrm{g} / \mathrm{l}$, presence of high levels of hydrocarbons in fish tissues, could be explained only through the process of both bioaccumulation and biomagnification. The quantities of heavy metals in the edible portions of the fishes are lower than upper limits prescribed by the ISO or other such agencies. Data, collected in general, indicated that accumulation of heavy metals, like hydrocarbons, is through gills which act as site for absorption/ adsorption and later transfer the pollutant to other tissues. No long-term effects, due to existing activities, on marine life, particularly fishes, are envisaged.

\section{Acknowledgement}

The author is deeply indebted to the Director, NEERI, Nagpur for providing facilities to carry out this research work being a project Assistant in EIRA Division (NEERI) and kind permission for this publication.

\section{References}

Boothe, P.N. and Presley, B.J. 1989. "Trends in sediment Trace Element Concentrations around Six Petroleum Drilling Platforms in the Northwestern Gulf of Mexico", Drilling Wastes edited by F.R. Engelhardt, J.P. Ray, A.H. Gillam, Elsevier, Appl. Sci., pp 3-21.

Clark, R.C. and Macleod, W.D. 1977. in Effects of Petroleum on Arctic and sub-Arctic Marine Environments and Organisms, Vol. I, Nature and fate of petroleum, edited by D.C. Malins (Academic Press, New York).

Corner, E.D.S. 1978. Pollution studies with Marine Plankton Part I, Petroleum Hydrocarbons and Related compounds, Adv. Mar. Biol., 15: 289-380.

Das, B., Khan, Y.S.A., Das, P. and Likhon, S.H. 2002. "Hydrocarbon Distribution in Flat Fish Psettodes Erumel (Pleuronectiformes) and Mussel Modiolus striatulus (Heterodonta) from the Southeast Coastal Region of Bangladesh", Ind. J. Marine Sci., 31(3): pp. 225-330.

Das, S., Patro, S.K. and Sahu, B.K. 2001. "Variation of Residual Mercury in Panaeid Prawns from Rushikulya Estuary East Coast of India", Ind. J. Marine Sci., 30(1): pp 33-37.

Mehta, P., et al. 1994. Ind. J. Marine Sci., 23: pp. 123-125.

Offshore Oil and Gas Environmental Effects, Monitoring, Approaches and Technologies by Armsworthy, Cranford and Lee, pp 244.

Simpson, A.C. 1968. "The Torrey Canyon Disaster and Fisheries Laboratory Leaflet", New Series No. 18 (Ministry of Agriculture, Fisheries and Food, U.K.).

\section{How to cite this article:}

Sonali Kumbhare, Dilip S. Ramteke and Pravin Charde. 2017. Accumulation of Heavy Metals and Poly Aromatic Hydrocarbons in Marine Fishes around offshore Oil and Gas fields in west coast of India. Int.J.Curr.Microbiol.App.Sci. 6(3): 490-499. doi: https://doi.org/10.20546/ijcmas.2017.603.057 